\title{
Empirical Evidence from the Indonesian Stock Exchange: The Impact of Dividend Policy Decisions on Sharia Share Prices
}

\author{
Abdul Kadir MS ${ }^{1}$, Burhannudin ${ }^{2}$, Khuzaini $^{3}$, Bustani $^{4}$ \\ ${ }^{1,3}$ Lecturer, Faculty of Economics, Islamic University of Kalimantan MAB Banjarmasin \\ ${ }^{4}$ Collegiate, Faculty of Economics, Islamic University of Kalimantan MAB Banjarmasin \\ ${ }^{2}$ Tutorize, Banjarmasin Open University, Indonesia \\ ${ }^{1}$ Correspondent: kadirabdul8452@gmail.com
}

\begin{tabular}{ll}
\hline Received & : August 08, 2021 \\
Accepted & : August 25, 2021 \\
Published & : October 31, 2021
\end{tabular}

Citation: MS, A.K., Burhannudin, Khuzaini, Bustani (2021). Empirical Evidence from the Indonesian Stock Exchange: The Impact of Dividend Policy Decisions on Sharia Share Prices. Ilomata International Journal of Tax \& Accounting.2(4),262-267.

https://doi.org/10.52728/ijtc.v2i4.352

\begin{abstract}
This paper aims to obtain empirical evidence of the impact of dividend policy decisions on sharia share prices. An exploratory investigation on 26 selected firms listed on the Indonesia Stock Exchange's Jakarta Islamic Index with the criteria of reporting complete financial statements for the 2014-2018 period. The secondary data were examined with 130 data and then processed using SPSS 23 packages, which were then included in the analysis using standard regression. The investigation's findings provide empirical evidence that dividend policy decisions have a significant effect on sharia share prices. This study provides a theoretical contribution to a limited study that explores dividend policy with Islamic share prices in the context of the stock exchange. In practice, this research provides significant insight regarding the dividend policy that the company decides to increase the effectiveness of financial management in the context of a company that is considered to have sharia shares on the stock exchange, considering that the company's business success can increase the economic growth of a country.
\end{abstract}

Keywords: Syaria Stock, Stock Price, Dividend Policy, Jakarta Islamic Index

\section{INTRODUCTION}

The capital market is viewed as crucial and significant as a driver for any country's economic sustainability (Bustani, 2020; Lusiana, 2020; Syofyan et al., 2020; Usman et al., 2021). In the framework of financial management, long-term viability is essential for future business challenges involving the company's dividend policy (Irton, 2020; Nambukara-Gamage \& Peries, 2020; Yan \& $\underline{\mathrm{Zhu}}, 2020)$. Dividend policy and its impact on share prices have always been a contested issue among experts (AlAli et al., 2019; Ayunku \& Apiri, 2020; Jovković et al., 2021; NambukaraGamage \& Peries, 2020). However, balancing the competing interests of various shareholders, and the dividend policy they pick may have a good or negative influence on the share price (Khan et al., 2018; $\underline{\text {, 2021) }}$.

Profit retention and profit-sharing are linked to dividend policy (Tiwari \& Pal, 2020). Profit-sharing can take the form of dividends or the buyback of issued shares (Charith \& Davydenko, 2021), 


\section{Empirical Evidence from the Indonesian Stock Exchange: The Impact of Dividend Policy Decisions on Sharia Share Prices}

MS, Burhannudin, Khuzaini, Bustani

therefore as result, one of the company's greatest strategic considerations is dividend policy decisions to show company performance (Khan et al., 2018; Rono \& Omoro, 2020; V, 2021). Dividend policy refers to a company's choice to distribute profits to shareholders in the form of

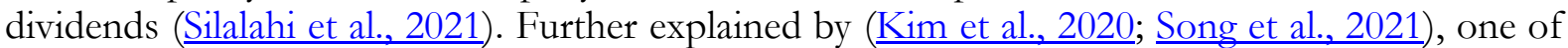
the most essential managerial decisions is dividend policy, which has been thoroughly researched in the financial literature. Before making profit-sharing investment decisions, dividend distribution policies should be thoroughly evaluated (Al-Sharif, 2020; Alnori \& Alqahtani, 2019).

Many theoretical and empirical research has concentrated on finding the elements that determine dividend policy, which has an impact on share prices. However, there is currently a scarcity of research on dividend policy and share prices in the context of Islamic companies. (Abedifar et al., 2020; Jaballah et al., 2018). Due to the uniqueness and nature of their commercial activities, the policy system of firms whose shares are categorized as sharia differs from conventional shares, making research on dividend policy on share prices crucially interesting for good management. (Shehata, 2021). The empirical literature study ( policy decisions affect share prices. The findings of follow-up research (Lasisi et al., 2020), show that dividends are essential for businesses, implying that signal theory is essential and that investors trust the information sent in dividend policy decisions. The paper goes on to say that corporations should make sure that good dividend policies and earnings per share rules are in place, as these have been shown to improve share price inflationary pressures empirically. Other studies disagree with the findings, such as (Adam et al., 2020; Barros et al., 2020), which found that dividend policy, along with asset growth, indicates a statistically irrelevant association to the company's stock market price, implying that dividend payments and share prices have a weak relationship.

The researchers discovered a dearth of studies related to this problem in numerous Asian nations after studying and evaluating the relevant literature. Thus, utilize data from the Indonesian stock exchange, this research aims to give empirical evidence of the impact of dividend policy decisions on sharia share prices. The report's implications can assist the management of companies with sharia-compliant shares in developing and analyzing more efficient dividend policies and financial management. This study is more essential from a larger perspective since the financial success of companies whose shares are categorized as sharia influences the economic growth of a country. Departing from the main issue and objectives of this study, the following set of hypotheses have been established: H1: There is a significant impact of dividend policy decisions on sharia share prices. Secondary data were processed using SPSS 23 statistical package, which was applied to perform standardized regression analysis.

\section{METHOD}

This research is an explanatory study using a quantitative approach to analyze the impact of dividend policy decisions on sharia share prices. The investigation was carried out in Indonesia's sharia stock market, which is represented by the Jakarta Islamic Index. The policies of companies whose shares are classified as sharia are different from conventional shares due to the uniqueness and nature of their business activities, which makes research on dividend policy with share prices very essential for effective management. The research population is 30 Islamic stock companies listed on the Jakarta Islamic Index. The sample is 26 companies using sampling criteria, namely, only companies reporting complete financial statements for the 2014-2018 period. The secondary data were analyzed by 130 data and then processed using SPSS 23 packages, which is then applied using standard regression analysis. 


\section{RESULT AND DISCUSSION}

The study's findings show that dividend policy decisions have a significant impact on sharia share prices. The dividend policy explains $56.9 \%$ of the variance $(\mathrm{R} 2=0.569)$ of the share prices. Beta is 0.754 and $\mathrm{p}$-value is $0.000(\mathrm{p}<0.05)$. This study found that dividend policy decisions have a significant impact on sharia share prices. Thus the hypothesis proposed H1 is accepted.

Dividend policy decisions have a significant impact on sharia share prices and contribute a 56.9\% impact on sharia share prices. This study shows that companies whose shares are classified as sharia greatly affect the role of dividend policy in increasing share prices. In addition, in the stock sector which is categorized as sharia in the context of Indonesia, it is essential to listen attentively to dividend policy decisions, because it has its own characteristics. The findings of the study are consistent with those of prior investigations (Syofyan et al., 2020), revealing that dividend policy has an effect on share prices. According to a study by (Imamah et al., 2019), sharia companies have larger dividend payouts, which is mostly due to large insider and external ownership. Furthermore, the firm size of sharia stocks has a significant impact on corporate governance because it is negatively associated with dividend payments when firm growth is high, but beneficial when firm size is low. Likewise (Lasisi et al., 2020), revealed that dividends are relevant for investors, meaning that signal theory is relevant, and investors believe in the information transferred in dividend policy decisions. Companies must ensure that good dividend policy decisions are enforced and the earnings per share policy are maintained because it has been empirically proven to increase share prices movements. As a result, the present value of share prices on dividend changes increases over time (Esteve et al., 2019), however, shareholders prefer early quick dividends, arguably a risk management tool used to reduce payback periods (Barros et al., 2021).

The implications of this study add to the realm of academic theory and practice. This research contributes to theory and practice in a variety of ways. As a result, current research fills the knowledge gap about dividend policy with Islamic share prices in Indonesia. At the identical time, the research stock is currently on the rise. Furthermore, this research contributes to the current empirical regard to the impact of dividend policy decisions on sharia share prices. This investigation has a wide range of implications for business management because it shows the business success of companies whose shares are classified as sharia greatly affects the economic growth of a country, this study has greater importance from a broader perspective.

Table 1 Regression Model

\begin{tabular}{|c|c|c|c|}
\hline & & \multirow{2}{*}{\multicolumn{2}{|c|}{ Model Summary }} \\
\hline Regression & Dividend Policy- Sharia Share Price & & \\
\hline Independent Variable & Dividend Policy & $\mathrm{R}$ & $754^{a}$ \\
\hline Dependent Variable & Sharia Share Price & R Square & .569 \\
\hline Constant & 2428.367 & \multirow[t]{6}{*}{ Adjusted R Square } & \\
\hline B & 27.761 & & .566 \\
\hline Std. Error & 2.134 & & \\
\hline Beta & .754 & & \\
\hline P-Value & .000 & & \\
\hline Conclusion & H1: accepted & & \\
\hline
\end{tabular}

Source: Secondary Data Processed, 2021 


\section{CONCLUSION}

The study's findings show that in the context of the Indonesian stock market, dividend policy decisions have a significant impact on sharia share prices. The findings also show that dividend policy intervention is needed to increase share prices in the context of companies classified as sharia. In future research, it will be useful to explore dividend policy with share prices by comparing stock exchanges across countries.

\section{REFERENCE}

Abedifar, P., Bouslah, K., Qamhieh Hashem, S., \& Song, L. (2020). How informative are stock prices of Islamic Banks? Journal of International Financial Markets, Institutions and Money, 66, 101203. https://doi.org/10.1016/j.intfin.2020.101203

Adam, H., Buckman, T., \& Setordzi, I. (2020). Impact of Dividend Policy on Share Price A Case of Listed Firms on the Ghana Stock Exchange. The International Journal of Business Management and Technology, 4(5), 51-61.

Al-Sharif, B. M. (2020). Dividend-Payout Policy and Share-Price Volatility in Islamic Banks: Evidence from Jordan. Asian Economic and Financial Review, 10(3), 266-274.

AlAli, M. S., Al-Yatama, S. K., AlShamali, N. M., \& AlAwadhi, K. M. (2019). The Impact of Dividend Policy on Kuwaiti Insurance Companies Share Prices. World Journal of Finance and Investment Research, 4(1), 34-39.

Alnori, F., \& Alqahtani, F. (2019). Capital structure and speed of adjustment in non-financial firms: Does sharia compliance matter? Evidence from Saudi Arabia. Emerging Markets Review, 39(August 2018), 50-67. https://doi.org/10.1016/j.ememar.2019.03.008

Ayunku, P. E., \& Apiri, T. R. (2020). Dividend Policy Impact on Market Value of Quoted Commercial Banks in Nigeria (2004-2018). Saudi Journal of Business and Management Studies, 5(3), 181-195.

Barros, V., Verga Matos, P., \& Miranda Sarmento, J. (2020). What firm's characteristics drive the dividend policy? A mixed-method study on the Euronext stock exchange. Journal of Business Research, 115(June), 365-377. https://doi.org/10.1016/j.jbusres.2019.11.042

Barros, V., Verga Matos, P., Miranda Sarmento, J., \& Rino Vieira, P. (2021). Do activist shareholders influence a manager's decisions on a firm's dividend policy: A mixed-method study. Journal of Business Research, 122, 387-397.

Bustani, B. (2020). The Effect of Return on Assets (ROA), Net Profit Margin (NPM), Dividend Payout Ratio (DPR), and Dividend Yield (DY) on Stock Prices in the Sub sectors insurance Company Listed in Indonesia Stock Exchange Period 2015-2018. Ilomata International Journal of Tax \& Accounting, 1(3), 170-178.

Charith, K., \& Davydenko, A. (2021). Informational Value of Dividend Initiations : Impact of Cash Dividends on Share Prices of Manufacturing Companies in Sri Lanka. International Journal of Economics and Finance, 13(3), 13-30.

Esteve, V., Navarro-Ibáñez, M., \& Prats, M. A. (2019). Stock prices, dividends, and structural changes in the long-term: The case of U.S. North American Journal of Economics and Finance, 124.

Imamah, N., Lin, T. J., Suhadak, Handayani, S. R., \& Hung, J. H. (2019). Islamic law, corporate governance, growth opportunities and dividend policy in Indonesia stock market. Pacific Basin 
Empirical Evidence from the Indonesian Stock Exchange: The Impact of Dividend Policy

Decisions on Sharia Share Prices

MS, Burhannudin, Khuzaini, Bustani

Finance Journal, 55, 110-126.

Irton, I. (2020). The influence of dividend policy on sharia stock price volatility: A study on Indonesian stock exchange. International Journal of Research in Business and Social Science, 9(7), 8492.

Jaballah, J., Peillex, J., \& Weill, L. (2018). Is Being Sharia compliant worth it? Economic Modelling, 72(April 2017), 353-362. https://doi.org/10.1016/j.econmod.2018.02.011

Jovković, B., Vasić, A. S., \& Bogićević, J. (2021). Determinants of Dividend Policy: A Case of Serbia's B Banking Sector. Naše Gospodarstvo/Our Economy, 67(1), 13-22.

Khan, S., Malik, M. F., \& Khan, S. (2018). Impact of Dividend Policy on Share Price Evidence from Textile Sector PSX-100 Index. Global Social Sciences Review, III(IV), 616-630.

Kim, J. M., Yang, I., Yang, T., \& Koveos, P. (2020). The impact of R\&D intensity, financial constraints, and dividend payout policy on firm value. Finance Research Letters, 1-16.

Lasisi, I. O., Apochi, J. G., Baffa, A. M., \& Badawiyu, K. (2020). Dividend Policy and Share Price Volatility: Evidence from Listed Deposit Money Banks in Nigeria. Gusau Journal of Accounting and Finance, 1(2), 1-15.

Lusiana, H. (2020). The Effect of Return on Equity (ROE) and Earning per Share (EPS) on Stock Prices In Indonesia Stock Exchange 2015-2018. Ilomata International Journal of Tax and Accounting, 1(3), 132-138.

Nambukara-Gamage, B., \& Peries, S. T. (2020). The Impact of Dividend Policy on Shareholder Wealth: A Study on the Retailing Industry of Australia. Review of Integrative Business and Economics Research, 9(1), 38-50.

Rono, C. C., \& Omoro, N. O. (2020). Dividend Policy and Share Price Volatility Among Insurance Companies Listed at Nairobi Securities Exchange. Business, Management and Economics Research, 6(1), 1-12.

Shehata, N. (2021). Board National Diversity and Dividend Policy: Evidence from Egyptian listed companies. Finance Research Letters, May, 102132. https://doi.org/10.1016/j.frl.2021.102132

Silalahi, A. S., Fachrudin, K. A., \& Sianipar, A. S. (2021). Analysis of the Bank Specific Factors, Macroeconomics and Oil Price on Dividend Policy. Analysis International Journal of Energy Economics and Policy, 11(2), 165-171.

Song, X., Yao, M., Su, W., \& Lin, D. (2021). The impact of ultimate controller's ownership on cash dividend policy based on a comparative analysis between owner-management and professional-management modes. North American Journal of Economics and Finance, 57(June 2020), 101439. https://doi.org/10.1016/j.najef.2021.101439

Syofyan, R., Putra, D. G., \& Aprayuda, R. (2020). Influence of Company Value Information, Dividend Policy, and Capital Structure on Stock Price. SAR (Soedirman Accounting Review): Journal of Accounting and Business, 6(2), 152-169.

Tiwari, S., \& Pal, D. (2020). Dividend Policy Decisions and Share Prices Relationship. Finance \& Accounting Research Journal, 2(2), 76-81.

Usman, B., Lestari, H. S., \& Sofyan, S. (2021). The Effect of Dividend Policy on Share Price Manufacturing Companies in Indonesia. Advances in Economics, Business and Management Research, 169, 117-122.

V, L. K. (2021). A Study on Dividend Policy and Its Impact on Stock Prices of Selected Companies 
Empirical Evidence from the Indonesian Stock Exchange: The Impact of Dividend Policy Decisions on Sharia Share Prices

MS, Burhannudin, Khuzaini, Bustani

with Reference to BSE Sensex 100. Palarch's Journal of Archaeology of Egypt/Egyptology, 18(363), 363-372.

Yan, Q., \& Zhu, H. (2020). Peer influence on dividend policy: Evidence from the Chinese stock market. Economics Letters, 192, 1-3. 